IZA DP No. 5064

The Prostitute's Allure: Examining Returns to Beauty, Productivity and Discrimination

Raj Arunachalam

Manisha Shah

July 2010 


\title{
The Prostitute's Allure: Examining Returns to Beauty, Productivity and Discrimination
}

\author{
Raj Arunachalam \\ University of Michigan \\ Manisha Shah \\ University of California, Irvine \\ and IZA
Discussion Paper No. 5064
July 2010 \\ IZA \\ P.O. Box 7240 \\ 53072 Bonn \\ Germany \\ Phone: +49-228-3894-0 \\ Fax: +49-228-3894-180 \\ E-mail: iza@iza.org
}

Any opinions expressed here are those of the author(s) and not those of IZA. Research published in this series may include views on policy, but the institute itself takes no institutional policy positions.

The Institute for the Study of Labor (IZA) in Bonn is a local and virtual international research center and a place of communication between science, politics and business. IZA is an independent nonprofit organization supported by Deutsche Post Foundation. The center is associated with the University of Bonn and offers a stimulating research environment through its international network, workshops and conferences, data service, project support, research visits and doctoral program. IZA engages in (i) original and internationally competitive research in all fields of labor economics, (ii) development of policy concepts, and (iii) dissemination of research results and concepts to the interested public.

IZA Discussion Papers often represent preliminary work and are circulated to encourage discussion. Citation of such a paper should account for its provisional character. A revised version may be available directly from the author. 


\begin{abstract}
The Prostitute's Allure: Examining Returns to Beauty, Productivity and Discrimination*

We estimate the earnings premium for beauty in an occupation where returns to physical attractiveness are likely to be important: commercial sex work. In the commercial sex market, perhaps more so than any other sector in the labor market, the beauty premium should be at the extreme due to the intimate interpersonal relationships required with clients. Therefore, the commercial sex sector provides the cleanest test for whether the beauty premium is driven solely by productivity. Somewhat surprisingly we find estimates that lie close to or comfortably within those for non-sex workers around the world. In fact, the estimated premium for above average beauty is only slightly larger than that estimated for women elsewhere, and the penalty for below average looks lies comfortably within the range of existing findings. We show that the beauty premium in the commercial sex market stems both from productivity and discrimination. In addition, including controls for personal characteristics (communication ability and desirability of personality) cuts the beauty premium by up to one-half. Our findings suggest that beauty premiums might be overestimated if measures akin to those in our dataset are not included in beauty regressions.
\end{abstract}

JEL Classification: J01, J71

Keywords: beauty premium, discrimination, sex markets

Corresponding author:

Manisha Shah

Department of Economics

University of California-Irvine

3151 Social Science Plaza

Irvine, CA 92697-5100

USA

E-mail: m.shah@uci.edu

\footnotetext{
* We thank Marianne Bitler, Jeff Borland, Kitt Carpenter, Andrew Clarke, Dan Hamermesh, Andrew Leigh, David Neumark, and Jeff Smith for helpful comments. This paper was previously circulated under the title "The Prostitute's Allure: The Return to Beauty in Commercial Sex Work."
} 
In recent years a growing body of research has attempted to uncover the labor market returns to ascriptive characteristics such as beauty. Central to this literature is the investigation of whether these returns to ascriptive characteristics represent discriminatory labor market outcomes or are emblematic of returns to productivity. Evidence of substantial sorting in the labor market based on beauty implies that the returns to beauty may not differ too much across occupations once the sorting has occurred. Since Hamermesh and Biddle (1994) first estimated the labor market returns to physical attractiveness, economists have discovered that a "beauty premium" exists in a variety of settings.

This paper builds upon a subset of the growing beauty premium literature that quantifies the reward for attractiveness as a wage premium in the labor market (Hamermesh and Biddle, 1994; Harper, 2000; Hamermesh et al., 2002; Leigh and Borland, 2007; Sachsida et al., 2003; Biddle and Hamermesh, 1998). At the core of this literature are two questions. First, is there a premium for beauty in the labor market? And more importantly, can this premium for beauty be attributed to productivity or discrimination? In order to isolate a premium for beauty, economists must first identify the impact of physical attributes as distinct from other characteristics that also drive returns in the labor market. This is particularly important as studies by psychologists show that beauty might be correlated with intelligence and other characteristics more traditionally related to human capital. Therefore, if these other characteristics are improperly measured or omitted from regression analysis, the impact of beauty on wages may be overestimated. In some studies of the returns to beauty, economists have attempted to control for such other characteristics but find no substantial reduction in the beauty premium when controlling for measures of self-reported self-confidence using respondents' answers to survey questions (Hamermesh and Biddle 1994; Leigh and Borland 2007- but see Doran and Hersch 2009 for a recent exception). Our data allow us to separate attractiveness from other worker characteristics which are generally unobserved by 
researchers. Our data include enumerators' assessments of sex workers' communication ability and personality, in addition to all the other various measures typically available in labor surveys. Controlling for these characteristics, substantially reduces the premium for attractiveness and almost eliminates the penalty for below average looks. Our data arguably more directly capture factors which are renumerated in the labor market and the findings suggest that beauty premiums might be overestimated if measures akin to those in our dataset are not included in beauty regressions.

More importantly whether a beauty premium exists is of little interest unless we can understand its sources. The three prominent explanation of the beauty premium are that beauty reflects productivity; that beauty derives returns in the labor market due to employer based discrimination (i.e. employers derive a taste based utility for interacting with beautiful employees); and that beauty derives returns in the labor market due to customer based discrimination (i.e. customers pay for the privilege of interacting with a beautiful employee). As Hamermesh and Biddle (1994) point out, the productivity based explanation for the beauty premium implies that looks should matter only in occupations where attractiveness is economically important. So in these occupations, even after sorting has occurred, we should still observe a substantial premium to beauty. In previous studies, economists have attempted to isolate occupations a priori where attractiveness is likely to matter in order to estimate if the beauty premium is large (Hamermesh and Biddle, 1994; Hamermesh et al., 2002; Sachsida et al., 2003; Biddle and Hamermesh, 1998).

We estimate the beauty premium for one such occupation: commercial sex work. In this occupation, perhaps more so than any other sector in the labor market the beauty premium should be at the extreme due to the intimate interpersonal relationships required with clients. Sex workers from all over the world report that beauty is an integral determinant of professional success (see Pisani (2008) for an example). Therefore, the commercial sex sector provides the cleanest test for whether the beauty premium is driven solely by productivity. In addition, because sex workers draw no income while waiting for clients, our 
data give us two different measures of earnings, price per transaction and weekly earnings, which we later exploit to test the productivity vs. discrimination hypotheses. When we estimate the beauty premium for sex workers using the standard methods in this literature, somewhat surprisingly we find estimates that lie close to or comfortably within those for non-sex workers around the world. In fact, the estimated premium for above average beauty is only slightly larger than that estimated for women elsewhere, and the penalty for below average looks lies comfortably within the range of existing findings. This result is consistent with Hamermesh and Biddle (1994), who also find that the productivity based explanation for the beauty premium fails to account for the entire premium.

The second explanation for the beauty premium is that it derives from employers tastes for interacting with beautiful employees. As such, this taste-based source of discrimination is similar to other types of discrimination in the labor market that have been probed for decades by labor economists. In our setting, we examine workers in which there are self-employed (e.g. street) and non self-employed (e.g brothels) workers allowing us to test for occupational sorting by beauty as well as to test for employer based discrimination. We find evidence of occupational sorting - that is we find overlapping but substantially shifted distribution of beauty wherein the non self-employed sex workers are more beautiful. However, the returns to beauty are substantially larger in the self-employed sector, suggesting that at least some component of the beauty premium is a productivity effect since explanations of the beauty premium as stemming solely from employer discrimination indicate that there should be no premium for the self-employed worker. Therefore, we find that the beauty premium cannot solely be explained by employer based discrimination either.

Finally there is the potential for a beauty premium due to customer based discrimination. Just as employers may derive utility from hiring attractive workers, clients of sex workers may also derive utility from hiring attracting sex workers. Customer based discrimination is also difficult to isolate from direct productivity effects of beauty. In part this may be because attractiveness itself is a feature of the service that many workers in the labor market provide. 
In our setting, this type of customer based discrimination is also difficult to sort out from direct productivity effects and employer based discrimination. However, restricting attention to brothel sex workers (whose hours are typically fixed by the employer and vary little across workers), we decompose the returns to beauty. We find that beauty increases both the price of sex transactions and the rate of client arrival. This finding is consistent with at least part of the beauty premium deriving from higher productivity. Although this type of decomposition exists for the laboratory context (e.g. Mobius and Rosenblat (2006)), our data provide the first glimpse into how beauty operates in the labor market. We do note the caveat that given the limitations of our data, we cannot separately identify (employer and/or customer) discrimination versus productivity. However, we can investigate whether the beauty premium is being solely driven by discrimination or productivity, and we can reject these hypotheses.

This paper makes three important contributions to the existing literature. First, we estimate the beauty premium in an occupation which requires intimate interpersonal contact, and therefore should be at the extreme. However, it is not. Second, our findings suggest that beauty premiums might be overestimated if measures akin to those in our dataset are not included in beauty regressions. Lastly, we show that the beauty premium in the commercial sex market, where productivity should matter, stems both from productivity and discrimination.

\section{Data}

As in many parts of the world, such as much of Latin America, Australia, New Zealand, and parts of Europe, the commercial sex sector is legal and regulated in Mexico and Ecuador. However, large-scale, representative surveys of sex workers are relatively rare since this is an extremely hard to reach population so it is unusual to find large representative datasets of 
sex workers. Given the financial turnover of the sex sector in most developing countries, ${ }^{1}$ the integral role this sector plays in the spread of sexually transmitted infections including $\mathrm{HIV} / \mathrm{AIDS}$, as well as the number of women working in this sector, ${ }^{2}$ there is a relative dearth of representative micro level data.

We draw data from two representative surveys of female sex workers: the first in 2001 in the Mexican states of Morelos and Michoacan, and the second in 2003 in eight major cities in Ecuador (Quito, Guayaquil, Machala, Esmeraldas, Santo Domingo, Quevedo, Milagro, and Daule). The Mexican survey was conducted as part of a behavioral surveillance of sex workers, and the Ecuador survey was the baseline survey for an HIV/AIDS prevention project targeting high-risk groups. In each city (in both countries), the universe of sex worker sites was first mapped to develop a sample frame. Potential worksites were identified in interviews with key informants, including sex workers, public health experts, nongovernmental organizations, taxi drivers, police, and brothel and nightclub owners. The survey was a random sample from this universe of sex worker sites. While the surveys were designed to maximize representativeness of the sex worker population, the study may undersample women who occasionally engage in commercial sex transactions solely from their homes.

In each country, a multidisciplinary team including local researchers developed the survey questionnaire. The surveys include personal characteristics of the sex workers and detailed earnings and labor supply information. In particular, we collected information on each worker's last three sexual transactions, including price as well as characteristics of each client. In both countries, the labor supply modules were modeled after their respective national labor and employment surveys, so we use standard measures from labor force surveys. ${ }^{3}$ Interviews

\footnotetext{
${ }^{1}$ For example, the Indonesian financial turnover of sex sector was estimated at between U.S 1.2 and 3.3 billion, or between 0.8 and $2.4 \%$ of the country's GDP. In Thailand, close to US 300 million is transferred annually from urban sex workers to rural areas in the form of remittances (Lim, 1998).

${ }^{2}$ For example, in Busia, Kenya $7 \%$ of working women were estimated to be sex workers in 1999; $0.5 \%$ in Mumbai, India in 2001; $1.8 \%$ in the Dominican Republic in 2001; and 7.4\% of working women in Belize were estimated to be sex workers in 2001 (Vandepitte et al., 2006).

${ }^{3}$ Further details about the data, sampling methods, and the market for commercial sex in Mexico and Ecuador are given in Gertler et al. (2005) and Gertler and Shah (2009).
} 
took place at sex worker workplaces and meeting points; response rates in both surveys were high (in Ecuador over 95 percent).

Summary statistics are reported in Table 1. In both Mexico and Ecuador, the mean age is 28 , and sex workers have completed six to seven years of schooling on average. Most sex workers have children (86\% in Ecuador and $74 \%$ in Mexico) and spend approximately 40 hours per week on the job. Sex workers in Ecuador earn $\$ 5$ US per hour, compared to approximately $\$ 12$ US (110 pesos) in Mexico. Sex workers in both countries earn more than their counterparts in the rest of the labor market, even after controlling for age, education, and location (Arunachalam and Shah, 2008).

\subsection{Measuring Beauty and Other Characteristics}

To minimize field officer biases in reporting (Baird et al., 2008), in Ecuador sex workers were hired and trained as enumerators partly to improve the reliability of the survey. Each enumerator was asked to assess a number of personal characteristics (beauty, weight, personality and communication skills), all from the perspective of a potential client. Since the enumerators themselves were experienced in the sex sector we believe their assessments of these characteristics are particulary reliable and thus minimize the potential for measurement error. All measures were scored from 1 to 5 with 1 being the "worst" score and 5 being the "best" score. For example, beauty was scored from 1 to 5, with 1 being the least attractive, and 5 being the most attractive. In Mexico, enumerators were additionally cued to score "average" sex workers with a rating of 3. Part A of Table 1 reports the breakdown of responses. Roughly $30 \%$ of the sex workers in Ecuador were rated as "most attractive" (with a mean score of 4.0); and roughly 7\% in Mexico were rated as "most attractive" (mean score is 2.9). To facilitate comparison across countries, we construct a collapsed measure of beauty, coding "average" as scoring a 4 in Ecuador or a 3 in Mexico. Using this definition in panel B of Table 1, 28.4\% of sex workers in Ecuador and 19.1\% in Mexico are coded as being above average beauty, while $21.8 \%$ in Ecuador and $32.3 \%$ in Mexico are coded as below 
average.

For sake of comparison, Figure 1 compares the distribution of beauty scores for the sex workers in our sample to that of Canadian and American non-sex workers given in Hamermesh and Biddle (1994). ${ }^{4}$ Strikingly, comparing distributions reveals far more "most attractive" scores in our sample, consistent with the occupational sorting found in Hamermesh and Biddle (1994) and Harper (2000). Formalizing this result requires a strong assumption that the sex workers' mean corresponds to that of workers elsewhere, which may not hold since (unlike in other studies) our measure is occupationally defined, in that enumerators assessed beauty specifically from prospective clients' point of view.

One appealing feature of our data is that enumerators were also asked to rate other personal characteristics of each sex worker. Each enumerator rated the sex worker's communication skills and personality from the point of view of a prospective client, using the same 1-5 scale as for beauty. As with beauty, we report both the continuous measure and collapse these measures into "above" and "below" average in Panel B of Table 1. Panel C reports the mean and standard deviation of the continuous measures. Our findings suggest it is extremely important that we have measures of these other characteristics as it may be the case that beauty is in fact a proxy for other characteristics that draw returns in the labor market.

In order to ascribe a premium to physical attributes, we need to be careful to control for these things. However, typically controls are not very satisfactory - and rely on self-reports (Hamermesh and Biddle 1994; Leigh and Borland 2007). Even then, paper beauty may still capture other aspects of physicality rather than genetic attributes, for instance dress, make-up (Hamermesh et al., 2002), or even the economic value of teeth (Glied and Neidell, forthcoming). Our data allow us to separate attractiveness from other worker characteristics which are often unobserved by researchers and the measures are particularly helpful because

\footnotetext{
${ }^{4}$ Unfortunately we are unaware of any datasets containing beauty measures of non-sex workers in Mexico or Ecuador.
} 
they are rated by enumerators experienced in the relevant sector and who can plausibly rate these characteristics from the customers' perspective. Furthermore, the fact that these characteristics are correlated with beauty in the data indicate that the beauty premium will be overestimated if such variables are omitted in the regression analysis.

The enumerators were also asked to assess the sex worker's weight. In the Mexico survey, the responses were coded in the same manner as the other personal characteristics; $27 \%$ are above average and $29 \%$ are below average weight. In Ecuador, the question was scaled differently, with 1 being "fat" and 5 being "skinny". For the Ecuador sample, our collapsed categories are "fat" $(=1)$, "skinny" $(=5)$, and "other weight" $(=2,3$, or 4$)$. In Ecuador, $4 \%$ of sex workers are rated as fat and $28 \%$ as skinny.

Finally, we construct a measure of the sex worker's health status since many of the previous beauty papers include measures of health status as a control variable in the regression analysis. In the commercial sex sector, the most important marker of good health is sexually transmitted infection (STI) status. In Mexico, respondents were asked whether they had vaginal problems or symptoms of an STI infection in the past year; sixteen percent responded positively. The Ecuador sample does not rely on self-reported STI status; there, biologicals (blood and urine samples) were collected from every sex worker at the time of the survey. Eight percent of sex workers in Ecuador tested positive for an STI (chlamydia, gonorrhea, and/or syphilis).

\section{Estimating the Beauty Premium}

Our estimation strategy draws from that of previous studies of the beauty premium (see for example Hamermesh and Biddle (1994) and Hamermesh et al. (2002)). We use hourly wages as our dependent variable and continuous as well as collapsed beauty categories to allow for direct comparisons of our esimates with other estimates in the literature. While we make no attempt to estimate a structural model, we follow the literature in employing a large number of control variables to account for determinants of earnings. We use two sets 
of controls. The first, $C_{1}$, includes linear and quadratic terms for age, and years of schooling; as well as dummies for marital status, children, and city. The second, $C_{2}$, includes place of birth, health, weight, indicators referring to sector of work (employed or self-employed) ${ }^{5}$ and years of experience as a sex worker. Since weight may serve as a component of beauty, we run all specifications excluding weight as a control; all results are qualitatively similar. To control for the fact that interviewers may use different scales in assessing characteristics of their respondents, we include enumerator fixed effects in all specifications.

In Table 2, we report results from OLS regressions of log hourly wages on our beauty measures. Column 1 of Panel A reports results for the Ecuador sample, where log hourly wages are regressed on the continuous measure of attractiveness with controls $C_{1}$; column 2 adds to $C_{1}$ the additional control variables in $C_{2}$. The estimated coefficient on beauty declines slightly when the additional controls are added, but in both specifications remains statistically and economically significant. The coefficient of .13 in Column 2 corresponds to a one standard deviation increase in beauty yielding a ten percent increase in hourly wages. Columns 5 and 6 reproduce the estimation for the Mexico sample. There, the estimated coefficient drops substantially when the controls in $C_{2}$ are added. The resulting beauty premium in Column 6 is very similar to that in Ecuador; the coefficient of .16 corresponds to a one standard deviation increase in beauty yielding a fifteen percent increase in hourly wages.

Panel B reproduces the same specifications using the collapsed beauty categories. In Column 1 , the coefficient on the above average beauty dummy controlling for $C_{1}$ is .20 , which declines slightly to .17 when controls $C_{2}$ are added (Column 2). Given the semilog specification, these translate to a $22 \%$ and a $19 \%$ premium for above average beauty, respectively. The penalty for below average beauty in Ecuador is fourteen percent using $C_{1}$ controls and nine percent using the full set of controls. As with the results from panel A, the beauty

\footnotetext{
${ }^{5}$ Sector of work could be considered endogenous, but our results do not vary significantly with or without sector controls so we include them.
} 
premium is larger in Mexico; the estimated coefficients using $C_{1}$ and $C_{2}$ translate to a $55 \%$ and $35 \%$ premium, respectively. Similarly, the penalty for below average beauty in Mexico is slightly higher than in Ecuador; the estimate in Column 5 translates to a $23 \%$ penalty. Once $C_{2}$ controls are added (Column 6), the estimated penalty is eleven percent, although the coefficient is no longer statistically significant.

The premium for above average beauty in sex work is, as we might expect, larger than that estimated for women elsewhere. However, somewhat surprisingly our estimates are fairly similar to the previous literature on beauty premiums. ${ }^{6}$ For example, the premium for a sample of women in China is under ten percent (Hamermesh et al., 2002), while estimates from the United States and Canada range from four to seven percent (Hamermesh and Biddle, 1994; Mocan and Tekin, forthcoming). However, our estimated penalties for plainness lie comfortably within estimates elsewhere, which range from above thirty percent in China to approximately five percent in North America.

\section{$3 \quad$ Beauty and Other Personal Characteristics}

Does beauty directly affect earnings, or is attractiveness effectively serving as researchers' proxy for self-confidence or other characteristics that command a premium in the labor market? Attempts to control for such characteristics have failed to eliminate or substantially reduce the estimated beauty premium. Hamermesh and Biddle (1994) employ a psychometric measure of self-esteem, and Leigh and Borland (2007) use self-reported beauty to proxy for self-confidence; neither study finds a decline in the beauty premium once these controls are added. Importantly, however, both measures derive from respondents' self-reports, while the labor market may respond to personal characteristics that individuals systematically misreport when describing themselves. An appealing feature of our data is that we are able to control for communication skills and desirability of personality; in focus groups, sex

\footnotetext{
${ }^{6}$ See https://webspace.utexas.edu/hamermes/www/BeautyStudiesSummary.htm for a summary of findings from a number of studies.
} 
workers identified both characteristics as important assets. An additional attraction of our data is that enumerators were asked to rate sex workers' from the point of view of potential clients, providing us with an external measure of typically unobserved characteristics.

Turning back to Panel A of Table 2, controlling for the sex worker's score for communication skills (in addition to the controls in $C_{1}$ and $C_{2}$ ) reduces the estimated beauty premium in Ecuador but not in Mexico. The coefficient on the beauty score in Ecuador reduces to .08 (Column 3); a one standard deviation increase in beauty yields a six percent increase in hourly wages. Once the score for desirability of personality is added to the set of controls, the point estimate on beauty declines further. In Ecuador, the coefficient on beauty falls to .06 and is no longer statistically significant (Column 4), while in Mexico the coefficient on beauty in Column 8 remains weakly significant but declines in magnitude, so that a one standard deviation increase in beauty yields a ten percent increase in wages. Using the collapsed categories for the personal characteristics produces qualitatively similar results.

Insofar as our findings may extend to other settings, they suggest that beauty's earnings premium may typically be overestimated, since attractiveness is correlated with typically unobserved characteristics - such as intelligence (Kanazawa and Kovar, 2004) - that draw a premium in the labor market. Our findings are similar to Doran and Hersch (2009) who also find the beauty premium decreases (and even disappears in some cases) once other ascriptive characteristics are included in the regressions. Furthermore, while our data do not allow us to explore this channel, beauty may determine aspects of human capital formation which in turn affect labor market returns (Mocan and Tekin, forthcoming; Persico et al., 2004).

One might worry that these results are being driven by multicollinearity between personality, communication skills, and beauty. In fact, the correlation coefficients between beauty and the other ascriptive characteristics (personality and communication skills) range from 0.4 to 0.7 . However, the evidence from the regression results does not necessarily support this claim. The magnitude of the coefficients on the beauty measures decrease substantially once we include the other ascriptive characteristics - it is not the case that the standard 
errors blow up as multicollinearity would suggest.

\section{Beauty and Productivity}

As Hamermesh and Biddle (1994) point out, a model in which the returns to beauty solely derives from productivity differences implies that workers looks should matter only in occupations in which attractiveness is important. In their study of ad executives (Pfann et al., 2000), as well as others studies of salewomen (Sachsida et al., 2003), researchers have attempted to isolate occupations a priori where looks are thought to be important in order to assess the productivity based explanation for the beauty premium. In this paper, we isolate an occupation in which perhaps more so than any other sector in the labor market, looks are important. Sex work intrinsically requires interpersonal contact with clients. Sex workers are gauged on their attractiveness by clients, employers and each other and much of their professional success is thought to depend on beauty. Qualitatively beauty draws returns in sex work; therefore we would expect that according to a productivity based explanation of the beauty premium in the labor market as a whole, that the beauty premium for prostitution would be at the extreme. However, we find that the estimated beauty premium for beauty in the sex market is actually quite similar to previous literature. This is consistent with Hamermesh and Biddle (1994) who interpret the lack of variation in the beauty premium across occupations in which looks matter as a rejection of a solely productivity based model of the beauty premium.

A natural question that emerges is whether the beauty premium derives solely from discrimination or whether attractiveness has a productivity component as well. As a crosssection of workers in one occupation, our data do not allow us to cleanly identify discrimination against plainness from productivity effects of attractiveness. Still, by exploiting features

of the commercial sex sector and our data, we devise two tests which test whether the beauty premium solely stems from discrimination, and we can reject this hypothesis. 


\subsection{Evidence from Sectoral Returns}

Since explanations of the beauty premium as stemming solely from employer discrimination indicate that there should be no premium for the self-employed (Biddle and Hamermesh, 1998), our first test for productivity effects examines the beauty premium across sectors of the sex market. ${ }^{7}$ As in other industries often characterized as "informal," a substantial fraction of sex workers in Ecuador and Mexico are self-employed. Most self-employed sex workers engage in street transactions, but others arrange to meet clients at home. Possibly because sex work is legal in the two countries, self-employed sex workers do not report to pimps or other principals, and in most cases make arrangements with clients without intermediaries. Sex workers may also work at establishments such as brothels or nightclubs; we define such workers as non-self-employed. While some may enjoy considerable flexibility in choice of client, most non-self-employed sex workers are hired by the brothel or club owner and, in the case of brothels, are typically assigned fixed hours of work.

Sex workers, like taxi drivers, receive renumeration for "working" but not while waiting for customers. Since their wage varies by transaction numbers, our dependent variable of interest is price per transaction. ${ }^{8}$ Substantial evidence indicates that transaction price responds to client characteristics and transaction type (Gertler et al., 2005; Arunachalam and Shah, 2009), and the advantage of using price means we can include client and transaction characteristics as controls. For example, sex workers may see random clients in the brothel but regulars on the street, i.e clients might be different in the different sectors, and so we control for potential demand side heterogeneity.

Table 3 presents summary statistics of beauty by sector at the transaction level. In both Mexico and Ecuador, self-employed sex workers score lower on attractiveness, both for the continuous measure as well as the collapsed categories. This suggests that employers,

\footnotetext{
${ }^{7}$ As in Biddle and Hamermesh (1998), in this discussion of employer discrimination we consider the firm - brothel or nightclub - as employer, as distinct from the clients themselves.

${ }^{8}$ Previously we used log hourly wage as the dependent variable in order to compare our estimates to all the other beauty premium estimates in this literature.
} 
or owners of brothels and nightclubs, might be discriminating against less attractive sex workers and not offering them employment. ${ }^{9}$ However, when we test for differential returns to beauty by sector, we find that the premium is actually larger in the self-employed sector.

We run these regressions at the transaction level since the dependent variable is price per transaction and cluster at the sex worker level since we have multiple transactions per woman. Tables 4 and 5 display the results of OLS regressions of the price of a sex transaction on the worker's beauty score, with standard errors clustered at the sex worker level. Specification $C_{1}$ includes controls for linear and quadratic terms in age, schooling, as well as dummies for marital status, children, city, and interviewer fixed effects; $C_{2}$ adds place of birth, health status, weight, and years of experience as a sex worker; $C_{3}$ adds the communication skills score and the desirability of personality; and $C_{4}$ includes transaction characteristics (anal, oral, vaginal, and non-sex services) and client characteristics (regular, clean, handsome, rich, foreign, and risky).

The findings suggest that a one standard deviation increase in beauty translates to a six percent additional beauty premium in Ecuador's self-employed sector; the equivalent figure in Mexico is a nine percent additional premium (Table 5). Panel B of Table 4 reveals the same pattern of an additional plainness penalty in Ecuador and an additional attractiveness premium in Mexico for self-employed sex workers (Panel B Table 5).

Since workers select into sectors, the OLS results presented in Tables 4 and 5 may partly be driven by heterogeneity in unobserved characteristics. Therefore, we consider specifications that include worker fixed effects to control for selection into sector. We are able to do this because a small percentage of our sex workers (approximately 3\%) switched sectors (brothel to street and street to brothel) in their last three transactions. Since we have data on three transactions per sex worker, we are able to run sex worker fixed effects models which control for unobservable sex worker heterogeneity. ${ }^{10}$ Columns 5 -6 of Table 4 report

\footnotetext{
${ }^{9}$ We also find that self-employed sex workers score lower in their communication skills and personality (results available upon request).

${ }^{10}$ We acknowledge that there might be selection into being a switcher, but still claim these results are
} 
the results for Ecuador and columns 5-6 of Table 5 for Mexico. In Ecuador, controlling for sectoral sorting in the fixed effects model yields a substantially larger estimate of the additional beauty premium in the self-employed sector. In Mexico, the fixed effects results are inconclusive as the estimated coefficients are substantively small and not significantly different from zero.

Combined, these findings are consistent with both sectoral sorting and a productivitybased interpretation of the beauty premium. While the test does not rule out employer based discrimination as a potential factor affecting the sectoral distribution of beauty, the existence of a larger beauty premium for self-employed workers suggests that productivity is also a component of the beauty premium; otherwise we would not find a beauty premium for self-employed sex workers. It is also consistent with occupational sorting into the sector in which beauty is more highly renumerated. The summary statistics provide suggestive evidence that prettier women sort into the non-self employed sector. This might also suggest that owners of brothels and nightclubs discriminate against uglier women, employing more attractive sex workers.

\subsection{Decomposing the Beauty Premium}

In addition to comparing returns for self-employed workers, we can locate the productivity component of the beauty premium by an accounting decomposition of earnings that yields a natural interpretation within a Becker-style model of taste discrimination. In this section, we restrict attention to brothel workers. We do this because while they are typically assigned fixed shifts by brothel owners, brothel sex workers are paid by transaction price rather than by wage. Brothel workers draw no income while waiting for a solicitation. Recall our data give us two different measures of earnings: price per transaction and weekly earnings; where price per transaction is the price paid by the client and weekly earnings is the price paid per transaction $\times$ the number of clients last week. Thus, we can decompose beauty's effect more likely to control for unobservable sex worker heterogeneity relative to the OLS results. 
on weekly earnings into an effect on rate of client arrival and on the price per transaction. Assuming a competitive market, the price per transaction equals the marginal product, and thereby captures all observable and unobservable attractions of one sex worker relative to another. Then, if clients are more likely to "hire" a beautiful sex worker, but she draws no higher price for the transaction, this is suggestive of taste discrimination - clients have a taste for beautiful workers despite their offering no higher productivity. Here, by assumption, the price captures all productivity effects, while the rate of client arrival captures discrimination.

Since our data include the price for the sex worker's previous three transactions, we can approximate her weekly earnings $Y$ as: $Y=\frac{1}{3}\left(\sum_{j=1}^{3} p_{j}\right) T$ where $j$ indexes transactions; $T$ is the number of transactions per week; and $p$ is the price per transaction. Expanding this expression to account for hours worked, we have: $Y=\frac{1}{3}\left(\sum_{j=1}^{3} p_{j}\right) \frac{T}{h_{C}} \frac{h_{C}}{h} h$, where $h$ is the number of hours worked per week and $h_{C}$ is the number of hours spent with clients per week. Focus group interviews indicate that unlike the street or other sectors of the commercial sex market, brothel workers are typically assigned fixed weekly schedules in eight or ten hour shifts, mitigating the simultaneity problem wherein hours worked is partly determined by earnings. Similarly, transactions per hour, $\frac{T}{h_{C}}$, is a parameter given by the nature of work; most brothel sex workers report transactions of 20-25 minutes, with little variation.

Under these assumptions, this earnings decomposition yields a natural interpretation under Becker's (1971) theory of taste discrimination. Brothel workers' pay derives from transactions with clients; assuming away on-the-job leisure, all brothel workers seek to maximize the fraction of "productive" time spent with clients, or the fraction $\frac{h_{C}}{h}$. Here, $\frac{h_{C}}{h}$ is a measure of the rate of client arrival, analogous to a firm's hiring rate in a discrimination model, and is given to a sex worker as a function of her characteristics, including beauty. In equilibrium, the transaction price $p$ equals the sex worker's marginal product. The price increase accorded to beauty represents the productivity-based component of the beauty premium, and the responsiveness of the rate of client arrival to beauty captures the contribution of taste-based discrimination. In this way, we are specifying a conservative test of the pro- 
ductivity effect of the beauty premium, since returns deriving from increased rate of client arrival are attributed by construction to discrimination.

In Table 6 we report results from regressing $\log Y, \log \frac{h_{C}}{h}$, and $\log$ average price on beauty and our set of control variables, restricting the analysis to brothel sex workers in Ecuador since we did not collect information on time spent with clients in Mexico. These regressions are estimated at the sex worker level since earnings are measured at the sex worker level. The control variables $C_{1}$ and $C_{2}$ remain the same as before; and we also include controls for communication skills and personality $\left(C_{3}\right)$ in the last column for each dependent variable.

Columns 1-3 of Table 6 report the beauty premium for brothel workers using the continuous measure (Panel A) and collapsed measure (Panel B) of beauty. The estimates are slightly larger than those reported in Table 2, although this is partly driven by the fact that we are now looking at weekly rather than hourly earnings. The coefficient of .19 in Column 2 of Table 6 indicates that a one standard deviation increase in beauty increases sex worker earnings by approximately fifteen percent. The magnitudes of the beauty premium and plainness penalty using the collapsed measure of beauty in Panel B are also larger than before; sex workers with above average beauty draw a $21 \%$ premium and sex workers with below average beauty are penalized by $21 \%$.

Columns 4-6 of Table 6 regress our measure of rate of client arrival on the beauty measures. We generate the dependent variable, $\log \frac{h_{C}}{h}$, by dividing "average hours spent with clients last week" by the "total hours worked last week" and then taking the log of that ratio. Controlling for $C_{1}$ and $C_{2}$ in Panel A, Column 5, a one standard deviation increase in beauty increases the ratio of client hours to hours worked by approximately fifteen percent. Using the collapsed beauty measures in Panel B, the premium for above average beauty is approximately $19 \%$ in column 5 ; while the penalty for below average beauty is approximately 4 percent with a large standard error. The magnitude of both the continuous and collapsed category beauty measures decreases significantly in column 6 when we include the measure of sex worker communication and personality skills, and beauty becomes statistically 
insignificant.

In columns 7-9 of Table 6, we regress the log average transaction price on beauty. We find that for a one standard deviation increase in beauty, there is a 4 percent increase in average price. This effect holds even when we control for personality and communication skills (column 9). Similarly, there is both a beauty premium and plainness penalty (panel B). ${ }^{11}$ The results from Table 6 indicate that the beauty premium operates both through the price of each sex transaction as well as increasing the fraction of time spent productively on the job (i.e., engaged with clients). Beauty's effect on earnings is consistent both with a direct productivity effect of attractiveness as well as discrimination.

In Table 7 we attempt to trace out the channels through which beauty might be operating. We investigate how beauty affects transaction price as well as client type. Turning to the transaction level analysis in Table 7, we regress log transaction price on beauty, where standard errors are clustered at the sex worker level. In columns 1-3 of Panel A, the estimated beauty premium remains around three percent, until we add controls for client characteristics which slightly reduce the premium and increase the standard error so the the coefficient on the continuous beauty score is no longer statistically significant. Using the collapsed beauty categories in Panel B, the estimated premium for beauty is small and remains statistically insignificant, but the penalty for unattractiveness remains statistically significant at around five percent across specifications.

Since client characteristics reduce the coefficient estimates in all specifications, we directly investigate whether beauty increases a sex worker's ability to attract desirable clients by running linear probability models in Columns 4-11; results are qualitatively similar under probit models (not displayed). We find some evidence that beauty directly relates to client characteristics. For example, a one standard deviation increase in beauty increases the

\footnotetext{
${ }^{11}$ For robustness, we test whether the beauty premium results change once we control for hours worked in the price regressions in Table 6 (results available upon request from authors). The beauty premium results remain unchanged. Similarly, we control for average price in the rate of client arrival regressions in columns 4-6 and again the beauty premium results remain unchanged.
} 
probability of pairing with a clean client by approximately two percent. However, these sources of heterogeneity are unlikely to be major factors driving the beauty premium, as the estimates are substantively small and lose statistical significance when additional controls are added.

Put together, the results from the brothel workers indicate that the beauty premium operates both through the price of each sex transaction as well as increasing the fraction of time spent productively on the job (i.e., engaged with clients). Beauty's effect on earnings is consistent both with a direct productivity effect of attractiveness as well as discrimination, wherein beautiful sex workers are more likely to be "hired" by clients. In addition, it appears that beautiful sex workers are more productive than their less attractive coworkers, in that beauty significantly increases the price of a transaction. However, the magnitude of the coefficients suggest that the taste-based discrimination effect might dominate the productivity effect in the sex market; again noting that given the limitations of our data we are only able to provide suggestive evidence.

\section{Conclusion}

Perhaps more so than any other profession, commercial sex work inherently involves interpersonal contact with clients. A priori, we would expect a high beauty premium in occupations where attractiveness is productive. Interestingly, while the beauty premium for sex work in Mexico and Ecuador is only slightly larger than that found in other studies, the penalty for below average looks lies comfortably within the range of existing estimates. In addition, controlling for correlates of beauty that are rarely observed by researchers yet are likely determinants of income cuts our estimate of the beauty premium by up to one-half, suggesting that previous studies which do not control for other types of ascriptive characteristics may be overestimating the magnitude of the beauty premium.

We also investigate whether the beauty premium is being solely driven by discrimination or productivity. We can reject these hypotheses as our findings are consistent with at least 
some part of the beauty premium deriving from higher productivity and some part from discrimination. Given the importance of beauty in the sex market, this market allows for one of the cleanest tests of the productivity hypothesis since as Hamermesh and Biddle (1994) point out, the productivity based explanation for the beauty premium implies that looks should matter only in occupations where attractiveness is economically important. In these occupations, even after sorting has occurred, we should still observe a substantial premium to beauty. Somewhat surprisingly we find estimates that lie close to or comfortably within those for non-sex workers around the world. We explore the potential for employer based discrimination as well as customer based discrimination and find evidence that both types of discrimination are also at work. Given the cross sectional nature of our data, we cannot separately identify discrimination versus productivity; however, we can reject that the beauty premium is being solely driven by discrimination or productivity. 


\section{References}

Arunachalam, Raj and Manisha Shah, "Prostitutes and Brides?," American Economic Review: Papers E Proceedings, May 2008, 98 (2), 516-522.

_ and _ , "Compensated for Life: Sex Work and Disease Risk in Ecuador," 2009. Working Paper.

Baird, Sarah, Joan Hamory, and Edward Miguel, "Tracking, Attrition and Data Quality in the Kenyan Life Panel Survey Round 1 (KLPS-1)," 2008. Working Paper.

Becker, Gary S., The Economics of Discrimination, 2nd ed., University of Chicago Press, 1971.

Biddle, Jeff E. and Daniel S. Hamermesh, "Beauty, Productivity, and Discrimination: Lawyers' Looks and Lucre," Journal of Labor Economics, January 1998, 16 (1), 172-201.

Doran, Kirk and Joni Hersch, "How Robust is the Beauty Premium?," 2009. Working Paper.

Gertler, Paul and Manisha Shah, "Sex Work and Infection: What's Law Enforcement Got to Do with It?," 2009. Working Paper.

_ , _ , and Stefano Bertozzi, "Risky Business: The Market for Unprotected Commercial Sex," Journal of Political Economy, June 2005, 113 (3), 518-550.

Glied, Sherry and Matthew Neidell, "The Economic Value of Teeth," Journal of Human Resources, forthcoming.

Hamermesh, Daniel S. and Jeff E. Biddle, "Beauty and the Labor Market," American Economic Review, December 1994, 84 (5), 1174-1194.

_ , Xin Meng, and Junsen Zhang, "Dress for Success_-Does Primping Pay?," Labour Economics, 2002, $9(3), 361-373$.

Harper, Barry, "Beauty, Stature and the Labor Market: A British Cohort Study," Oxford Bulletin of Economics and Statistics, 2000, 62, 771-800.

Kanazawa, Satoshi and Jody L. Kovar, "Why beautiful people are more intelligent," Intelligence, 2004, 32, 227-243.

Leigh, Andrew and Jeff Borland, "Unpacking the Beauty Premium: Is it Looks or Ego?," 2007. Working Paper.

Lim, Lin Lean, The Sex Sector: The Economics and Social Bases of Prostitution in Southeast Asia, International Labor Organization, Geneva, 1998.

Mobius, Markus M. and Tanya S. Rosenblat, "Why Beauty Matters," American Economic Review, 2006, 96 (1), 222-235.

Mocan, H. Naci and Erdal Tekin, "Ugly Criminals," Review of Economics and Statistics, forthcoming.

Persico, Nicola, Andrew Postlewaite, and Dan Silverman, "The Effect of Adolescent Experience on Labor Market Outcomes: The Case of Height," Journal of Political Economy, 2004, 112 (5), 1019-1053.

Pfann, Gerard A., Jeff E. Biddle, Daniel S. Hamermesh, and Ciska M. Bosman, "Business Success and Businesses' Beauty Capital," Economics Letters, 2000, 67, 201-207.

Pisani, Elizabeth, The Wisdom of Whores: Bureaucrats, Brothels, and the Business of AIDS, Norton, 2008. 
Sachsida, Adolfo, Adriana Cristina Dornelles, and Carlos Wagner Mesquita, "Beauty and the Labor Market: Study One Specific Occupation," 2003. Working Paper.

Vandepitte, J, R Lyerla, G Dallabetta, F Crabb, M Alary, and A Buv, "Estimates of the Number of Female Sex Workers in Different Regions of the World," BMJ, 2006. 
Table 1: Descriptive Statistics

\begin{tabular}{|c|c|c|}
\hline & Ecuador & Mexico \\
\hline \multicolumn{3}{|l|}{ A. Appearance (percent) } \\
\hline Most Attractive $(=5)$ & 28.4 & 6.5 \\
\hline$(=4)$ & 49.8 & 13.1 \\
\hline$(=3)^{*}$ & 18.6 & 48.6 \\
\hline$(=2)$ & 2.85 & 25.0 \\
\hline Least Attractive $(=1)$ & 0.30 & 6.9 \\
\hline \multicolumn{3}{|l|}{ B. Collapsed categories (percent) } \\
\hline Above average beauty & 28.4 & 19.1 \\
\hline Below average beauty & 21.8 & 32.3 \\
\hline Above average communication & 32.7 & 35.5 \\
\hline Below average communication & 21.0 & 16.1 \\
\hline Above average personality & 29.8 & 22.6 \\
\hline Below average personality & 19.7 & 30.6 \\
\hline Fat & 3.9 & \\
\hline Skinny & 28.0 & \\
\hline Above average weight & & 26.6 \\
\hline Below average weight & & 29.3 \\
\hline \multicolumn{3}{|l|}{ C. Continuous measures(mean) } \\
\hline \multirow[t]{2}{*}{ Beauty } & 4.0 & 2.9 \\
\hline & $(.78)$ & $(.95)$ \\
\hline \multirow[t]{2}{*}{ Communication skills } & 4.1 & 3.2 \\
\hline & $(.86)$ & $(.96)$ \\
\hline \multirow[t]{2}{*}{ Personality } & 4.1 & 3.0 \\
\hline & $(.765)$ & $(1.0)$ \\
\hline \multirow[t]{2}{*}{ Weight } & 3.8 & 3.0 \\
\hline & $(1.1)$ & $(1.0)$ \\
\hline \multicolumn{3}{|l|}{ D. Other control variables (mean) } \\
\hline Married/Civil Union $(=1)$ & .49 & .22 \\
\hline Has children $(=1)$ & .86 & .74 \\
\hline Has STI $(=1)$ & .08 & .16 \\
\hline \multirow[t]{2}{*}{ Age (years) } & 27.9 & 27.7 \\
\hline & $(8.1)$ & $(7.9)$ \\
\hline \multirow[t]{2}{*}{ Education (years) } & 7.4 & 6.4 \\
\hline & $(3.4)$ & $(3.5)$ \\
\hline \multirow[t]{2}{*}{ Sex work experience (years) } & 4.3 & 6.7 \\
\hline & $(5.1)$ & $(7.1)$ \\
\hline \multirow[t]{2}{*}{ Hourly wages last week } & $5.2 \mathrm{US} \$$ & 110 pesos \\
\hline & $(8.95)$ & $(241.6)$ \\
\hline \multirow[t]{2}{*}{ Average transaction price } & $7.1 \mathrm{US} \$$ & 438 pesos \\
\hline & $(7.10)$ & $(428)$ \\
\hline \multirow[t]{2}{*}{ Work hours last week } & 39.8 & 43.5 \\
\hline & $(22.5)$ & $(18.5)$ \\
\hline \multirow[t]{2}{*}{ Hours spent with client last week } & 12.9 & $\mathrm{~N} / \mathrm{A}$ \\
\hline & $(88.4)$ & \\
\hline Observations & 1960 & 923 \\
\hline
\end{tabular}




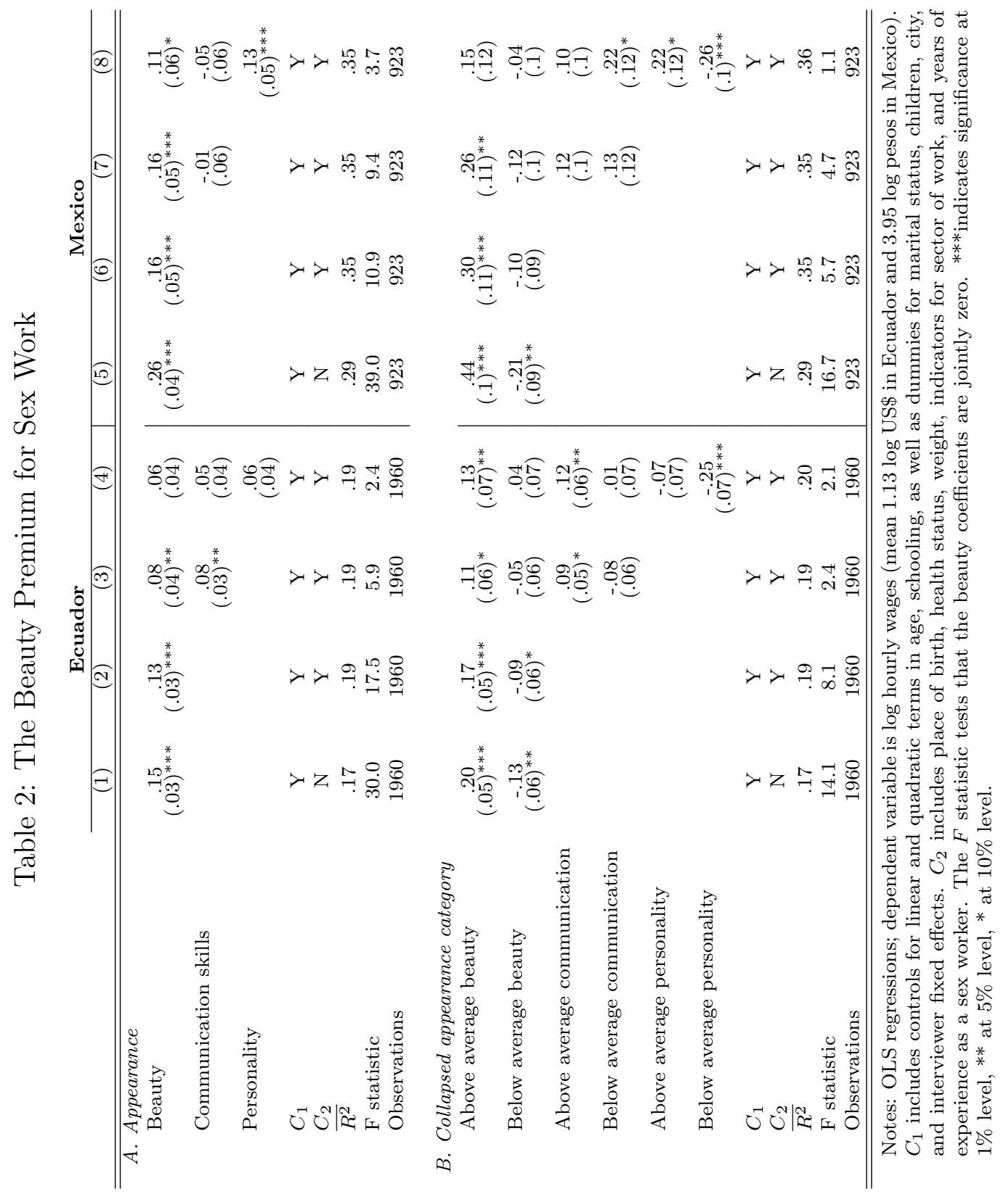


Table 3: Summary Statistics of Beauty by Sector

\begin{tabular}{lccc}
\hline Ecuador & Non-Self-Employed & Self-Employed & Difference \\
\hline \hline Beauty Score(1-5) & 4.11 & 3.66 & $0.45^{* * *}$ \\
& $(0.74)$ & $(0.87)$ & \\
Above average beauty $(=1)$ & 0.31 & 0.16 & $0.15^{* * *}$ \\
& $(0.46)$ & $(0.38)$ & \\
Below average beauty $(=1)$ & 0.17 & 0.42 & $-0.24^{* * *}$ \\
& $(0.38)$ & $(0.49)$ & \\
Observations & 6431 & 1613 & \\
\hline Mexico & Non-Self-Employed & Self-Employed & Difference \\
\hline \hline Beauty Score(1-5) & 2.90 & 2.68 & $0.22^{* * *}$ \\
& $(0.92)$ & $(0.95)$ & \\
Above average beauty $(=1)$ & 0.20 & 0.12 & $0.09^{* * *}$ \\
& $(0.40)$ & $(0.33)$ & \\
Below average beauty $(=1)$ & .30 & .39 & $-.09^{* * *}$ \\
& $(0.46)$ & $(0.49)$ & \\
Observations & 3205 & 667 & \\
\hline
\end{tabular}

Notes: We report the means and standard deviations of beauty by sector at the transaction level. ${ }^{* * *}$ indicates difference is statistically significant at $1 \%$ level, ${ }^{* *}$ at $5 \%$ level, ${ }^{*}$ at $10 \%$ level. 
Table 4: Differential Returns to Beauty by Sector in Ecuador?

Ecuador OLS

Ecuador FE

\begin{tabular}{|c|c|c|c|c|c|c|}
\hline & (1) & $(2)$ & $(3)$ & (4) & $(5)$ & $(6)$ \\
\hline \multicolumn{7}{|l|}{ A. Appearance } \\
\hline Beauty & $\begin{array}{c}.02 \\
(.01)\end{array}$ & $\begin{array}{l}.02 \\
(.01)\end{array}$ & $\begin{array}{c}-.007 \\
(.02)\end{array}$ & $\begin{array}{c}-.002 \\
(.02)\end{array}$ & & \\
\hline Self-Employed & $\begin{array}{l}-.12 \\
(.11)\end{array}$ & $\begin{array}{l}-.1 \\
(.11)\end{array}$ & $\begin{array}{l}-.1 \\
(.11)\end{array}$ & $\begin{array}{l}-.11 \\
(.11)\end{array}$ & $\begin{array}{c}-.56 \\
(.19)^{* * *}\end{array}$ & $\begin{array}{c}-.62 \\
(.18)^{* * *}\end{array}$ \\
\hline Beauty x Self-Employed & $\begin{array}{c}.07 \\
(.03)^{* *}\end{array}$ & $\begin{array}{c}.07 \\
(.03)^{* *}\end{array}$ & $\begin{array}{c}.07 \\
(.03)^{* *}\end{array}$ & $\begin{array}{c}.07 \\
(.03)^{* *}\end{array}$ & $\begin{array}{c}.2 \\
(.05)^{* * *}\end{array}$ & $\begin{array}{c}.21 \\
(.05)^{* * *}\end{array}$ \\
\hline Communication & & & $\begin{array}{l}-.01 \\
(.01)\end{array}$ & $\begin{array}{l}-.02 \\
(.01)\end{array}$ & & \\
\hline Personality & & & $\begin{array}{c}.05 \\
(.02)^{* * *}\end{array}$ & $\begin{array}{c}.05 \\
(.02)^{* * *}\end{array}$ & & \\
\hline Constant & $\begin{array}{c}1.62 \\
(.12)^{* * *}\end{array}$ & $\begin{array}{c}1.73 \\
(.14)^{* * *}\end{array}$ & $\begin{array}{c}1.69 \\
(.14)^{* * *}\end{array}$ & $\begin{array}{c}1.33 \\
(.15)^{* * *}\end{array}$ & $\begin{array}{c}1.72 \\
(.008)^{* * *}\end{array}$ & $\begin{array}{l}1.67 \\
(.01)^{* * *}\end{array}$ \\
\hline$C_{1}$ & $\mathrm{Y}$ & $\mathrm{Y}$ & $\mathrm{Y}$ & $\mathrm{Y}$ & & \\
\hline$C_{2}$ & $\mathrm{~N}$ & $\mathrm{Y}$ & $\mathrm{Y}$ & $\mathrm{Y}$ & & \\
\hline$C_{3}$ & $\mathrm{~N}$ & $\mathrm{~N}$ & $\mathrm{Y}$ & $\mathrm{Y}$ & & \\
\hline$C_{4}$ & $\mathrm{~N}$ & $\mathrm{~N}$ & $\mathrm{~N}$ & $\mathrm{Y}$ & $\mathrm{N}$ & $\mathrm{Y}$ \\
\hline$\overline{R^{2}}$ & .2 & .22 & .23 & .29 & .02 & .07 \\
\hline Observations & 8044 & 8044 & 8044 & 8044 & 8044 & 8044 \\
\hline $\begin{array}{l}\text { B. Collapsed appearance category } \\
\text { Above average beauty }\end{array}$ & $\begin{array}{l}.03 \\
(.02)\end{array}$ & $\begin{array}{l}.04 \\
(.02)\end{array}$ & $\begin{array}{l}.01 \\
(.03)\end{array}$ & $\begin{array}{l}.02 \\
(.03)\end{array}$ & & \\
\hline Below average beauty & $\begin{array}{l}-.02 \\
(.03)\end{array}$ & $\begin{array}{l}-.02 \\
(.03)\end{array}$ & $\begin{array}{l}.01 \\
(.03)\end{array}$ & $\begin{array}{l}.007 \\
(.03)\end{array}$ & & \\
\hline Self-Employed & $\begin{array}{l}.18 \\
(.03)^{* * *}\end{array}$ & $\begin{array}{c}.19 \\
(.03)^{* * *}\end{array}$ & $\begin{array}{c}.19 \\
(.03)^{* * *}\end{array}$ & $\begin{array}{l}.19 \\
(.03)^{* * *}\end{array}$ & $\begin{array}{c}.26 \\
(.05)^{* * *}\end{array}$ & $\begin{array}{l}.27 \\
(.05)^{* * *}\end{array}$ \\
\hline Above average beauty x Self-Employed & $\begin{array}{c}-.009 \\
(.07)\end{array}$ & $\begin{array}{c}-.005 \\
(.07)\end{array}$ & $\begin{array}{c}-.005 \\
(.07)\end{array}$ & $\begin{array}{l}-.02 \\
(.07)\end{array}$ & $\begin{array}{l}.13 \\
(.08)^{*}\end{array}$ & $\begin{array}{l}.11 \\
(.08)\end{array}$ \\
\hline Below average beauty x Self-Employed & $\begin{array}{l}-.12 \\
(.05)^{* *}\end{array}$ & $\begin{array}{l}-.12 \\
(.05)^{* *}\end{array}$ & $\begin{array}{l}-.12 \\
(.05)^{* *}\end{array}$ & $\begin{array}{l}-.12 \\
(.05)^{* *}\end{array}$ & $\begin{array}{c}-.26 \\
(.08)^{* * *}\end{array}$ & $\begin{array}{c}-.31 \\
(.08)^{* * *}\end{array}$ \\
\hline Above average communication & & & $\begin{array}{l}-.01 \\
(.02)\end{array}$ & $\begin{array}{l}-.03 \\
(.02)\end{array}$ & & \\
\hline Below average communication & & & $\begin{array}{l}.004 \\
(.03)\end{array}$ & $\begin{array}{c}-.001 \\
(.02)\end{array}$ & & \\
\hline Above average personality & & & $\begin{array}{l}.04 \\
(.03)\end{array}$ & $\begin{array}{l}.05 \\
(.03)\end{array}$ & & \\
\hline Below average personality & & & -.06 & $\begin{array}{l}-.05 \\
(.03)^{*}\end{array}$ & & \\
\hline Constant & $\begin{array}{l}1.69 \\
(.1)^{* * *}\end{array}$ & $\begin{array}{l}1.83 \\
(.13)^{* * *}\end{array}$ & $\begin{array}{l}1.85 \\
(.13)^{* * *}\end{array}$ & $\begin{array}{l}1.49 \\
(.13)^{* * *}\end{array}$ & $\begin{array}{c}1.71 \\
(.007)^{* * *}\end{array}$ & $\begin{array}{l}1.67 \\
(.01)^{* * *}\end{array}$ \\
\hline$C_{1}$ & $\mathrm{Y}$ & $\mathrm{Y}$ & $\mathrm{Y}$ & $\mathrm{Y}$ & & \\
\hline$C_{2}$ & $\mathrm{~N}$ & $\mathrm{Y}$ & $\mathrm{Y}$ & $\mathrm{Y}$ & & \\
\hline$C_{3}$ & $\mathrm{~N}$ & $\mathrm{~N}$ & $\mathrm{Y}$ & $\mathrm{Y}$ & & \\
\hline$C_{4}$ & $\mathrm{~N}$ & $\mathrm{~N}$ & $\mathrm{~N}$ & $\mathrm{Y}$ & $\mathrm{N}$ & $\mathrm{Y}$ \\
\hline$\overline{R^{2}}$ & .2 & .22 & .23 & .29 & .01 & .06 \\
\hline Observations & 8044 & 8044 & 8044 & 8044 & 8044 & 8044 \\
\hline
\end{tabular}

Notes: OLS regressions at the transaction level clustered at sex worker level (columns 1-4); and sex worker fixed effects regressions (columns 5-8); dependent variable is log price (US\$). $C_{1}$ includes controls for linear and quadratic terms in age, schooling, as well as dummies for marital status, children, city, and interviewer fixed effects. $C_{2}$ includes place of birth, health status, weight, and years of experience as a sex worker. $C_{3}$ is the communication skills score and the desirability of personality. $C_{4}$ iffcudes transaction characteristics (anal, oral, vaginal, and non-sex services) and client characteristics (regular, clean, handsome, rich, foreign, and risky). Non-self-employed is the omitted sector. $* * *$ indicates significance at $1 \%$ level, $* *$ at $5 \%$ level, $*$ at $10 \%$ level. 
Table 5: Differential Returns to Beauty by Sector in Mexico?

Mexico OLS

Mexico FE

\begin{tabular}{|c|c|c|c|c|c|c|}
\hline & $(1)$ & $(2)$ & $(3)$ & $(4)$ & $(5)$ & $(6)$ \\
\hline \multicolumn{7}{|l|}{ A. Appearance } \\
\hline Beauty & $\begin{array}{c}.18 \\
(.03)^{* * *}\end{array}$ & $\begin{array}{c}.11 \\
(.03)^{* * *}\end{array}$ & $\begin{array}{c}.07 \\
(.03)^{* *}\end{array}$ & $\begin{array}{c}.05 \\
(.03)^{*}\end{array}$ & & \\
\hline Self-Employed & $\begin{array}{c}-.88 \\
(.18)^{* * *}\end{array}$ & $\begin{array}{c}-.83 \\
(.17)^{* * *}\end{array}$ & $\begin{array}{c}-.81 \\
(.17)^{* * *}\end{array}$ & $\begin{array}{c}-.81 \\
(.16)^{* * *}\end{array}$ & $\begin{array}{l}.17 \\
. .31)\end{array}$ & $\begin{array}{l}.25 \\
(.31)\end{array}$ \\
\hline Beauty x Self-Employed & $\begin{array}{l}.12 \\
(.07)^{*}\end{array}$ & $\begin{array}{l}.1 \\
(.07)\end{array}$ & $\begin{array}{l}.1 \\
(.07)\end{array}$ & $\begin{array}{c}.09 \\
(.06)\end{array}$ & $\begin{array}{l}.001 \\
(.09)\end{array}$ & $\begin{array}{l}-.03 \\
(.09)\end{array}$ \\
\hline Communication & & & $\begin{array}{l}.02 \\
(.03)\end{array}$ & $\begin{array}{l}.03 \\
(.03)\end{array}$ & & \\
\hline Personality & & & $\begin{array}{c}.06 \\
(.03)^{* *}\end{array}$ & $\begin{array}{l}.05 \\
(.03)^{*}\end{array}$ & & \\
\hline Constant & $\begin{array}{c}5.32 \\
(.25)^{* * *}\end{array}$ & $\begin{array}{c}5.05 \\
(.55)^{* * *}\end{array}$ & $\begin{array}{l}4.97 \\
(.57)^{* * *}\end{array}$ & $\begin{array}{c}5.06 \\
(.61)^{* * *}\end{array}$ & $\begin{array}{c}5.76 \\
(.02)^{* * *}\end{array}$ & $\begin{array}{c}5.72 \\
(.02)^{* * *}\end{array}$ \\
\hline$C_{1}$ & $\mathrm{Y}$ & $\mathrm{Y}$ & $\mathrm{Y}$ & Y & & \\
\hline$C_{2}$ & $\mathrm{~N}$ & Y & Y & Y & & \\
\hline$C_{3}$ & $\mathrm{~N}$ & $\mathrm{~N}$ & Y & Y & & \\
\hline$C_{4}$ & $\mathrm{~N}$ & $\mathrm{~N}$ & $\mathrm{~N}$ & Y & $\mathrm{N}$ & $\mathrm{Y}$ \\
\hline$\overline{R^{2}}$ & .3 & .35 & .35 & .4 & .1 & .02 \\
\hline Observations & 3872 & 3872 & 3872 & 3872 & 3872 & 3872 \\
\hline \multicolumn{7}{|l|}{ B. Collapsed appearance category } \\
\hline Above average beauty & $\begin{array}{c}.33 \\
(.06)^{* * *}\end{array}$ & $\begin{array}{c}.24 \\
(.06)^{* * *}\end{array}$ & $\begin{array}{c}.19 \\
(.07)^{* * *}\end{array}$ & $\begin{array}{c}.18 \\
(.07)^{* * *}\end{array}$ & & \\
\hline Below average beauty & $\begin{array}{l}-.12 \\
(.05)^{* *}\end{array}$ & $\begin{array}{l}-.05 \\
(.05)\end{array}$ & $\begin{array}{l}.001 \\
(.05)\end{array}$ & $\begin{array}{c}.03 \\
(.05)\end{array}$ & & \\
\hline Self-Employed & $\begin{array}{c}-.65 \\
(.08)^{* * *}\end{array}$ & $\begin{array}{c}-.63 \\
(.07)^{* * *}\end{array}$ & $\begin{array}{c}-.63 \\
(.07)^{* * *}\end{array}$ & $\begin{array}{l}-.62 \\
(.07)^{* * *}\end{array}$ & $\begin{array}{l}.14 \\
(.09)^{*}\end{array}$ & $\begin{array}{l}.15 \\
(.09)^{*}\end{array}$ \\
\hline Above average beauty $\mathrm{x}$ Self-Employed & $\begin{array}{c}.64 \\
(.23)^{* * *}\end{array}$ & $\begin{array}{c}.56 \\
(.21)^{* * *}\end{array}$ & $\begin{array}{c}.54 \\
(.21)^{* *}\end{array}$ & $\begin{array}{l}.48 \\
(.2)^{* *}\end{array}$ & $\begin{array}{l}.07 \\
(.2)\end{array}$ & $\begin{array}{c}-.004 \\
(.2)\end{array}$ \\
\hline Below average beauty x Self-Employed & $\begin{array}{c}.03 \\
(.11)\end{array}$ & $\begin{array}{c}.03 \\
(.11)\end{array}$ & $\begin{array}{l}.04 \\
(.11)\end{array}$ & $\begin{array}{l}.03 \\
(.1)\end{array}$ & $\begin{array}{l}.21 \\
(.3)\end{array}$ & $\begin{array}{l}.2 \\
(.29)\end{array}$ \\
\hline Above average communication & & & $\begin{array}{l}.05 \\
(.05)\end{array}$ & $\begin{array}{l}.04 \\
(.05)\end{array}$ & & \\
\hline Below average communication & & & $\begin{array}{l}-.08 \\
(.06)\end{array}$ & $\begin{array}{l}-.1 \\
(.06)\end{array}$ & & \\
\hline Above average personality & & & $\begin{array}{c}.06 \\
(.07)\end{array}$ & $\begin{array}{l}.04 \\
(.07)\end{array}$ & & \\
\hline Below average personality & & & $\begin{array}{l}-.1 \\
(.05)^{* *}\end{array}$ & $\begin{array}{l}-.09 \\
(.05)^{*}\end{array}$ & & \\
\hline Constant & $\begin{array}{c}5.92 \\
(.24)^{* * *}\end{array}$ & $\begin{array}{c}5.81 \\
(.53)^{* * *}\end{array}$ & $\begin{array}{c}5.82 \\
(.56)^{* * *}\end{array}$ & $\begin{array}{c}5.83 \\
(.61)^{* * *}\end{array}$ & $\begin{array}{c}5.75 \\
(.02)^{* * *}\end{array}$ & $\begin{array}{c}5.71 \\
(.02)^{* * * *}\end{array}$ \\
\hline$C_{1}$ & $\mathrm{Y}$ & Y & $\mathrm{Y}$ & Y & & \\
\hline$C_{2}$ & $\mathrm{~N}$ & $\mathrm{Y}$ & $\mathrm{Y}$ & $\mathrm{Y}$ & & \\
\hline$C_{3}$ & $\mathrm{~N}$ & $\mathrm{~N}$ & Y & Y & & \\
\hline$C_{4}$ & $\mathrm{~N}$ & $\mathrm{~N}$ & $\mathrm{~N}$ & $\mathrm{Y}$ & $\mathrm{N}$ & $\mathrm{Y}$ \\
\hline$\overline{R^{2}}$ & .31 & .35 & .36 & .40 & .10 & .01 \\
\hline Observations & 3872 & 3872 & 3872 & 3872 & 3872 & 3872 \\
\hline
\end{tabular}

Notes: OLS regressions at the transaction level clustered at sex worker level (columns 1-4); and sex worker fixed effects regressions (columns 5-8); dependent variable is log price (Mexican pesos). $C_{1}$ includes controls for linear and quadratic terms in age, schooling, as well as dummies for marital status, children, city, and interviewer fixed effects. $C_{2}$ includes place of birth, health statys weight, and years of experience as a sex worker. $C_{3}$ is the communication skills score and the desirability of personality. $C_{4}$ includes transaction characteristics (anal, oral, vaginal, and non-sex services) and client characteristics (regular, clean, handsome, rich, foreign, and risky). Non-self-employed is the omitted sector. ${ }^{* * *}$ indicates significance at $1 \%$ level, ${ }^{* *}$ at $5 \%$ level, ${ }^{*}$ at $10 \%$ level. 
Table 6: Decomposing the Premium for Brothel Workers in Ecuador

\begin{tabular}{|c|c|c|c|c|c|c|c|c|c|}
\hline & \multicolumn{3}{|c|}{$\log Y$} & \multicolumn{3}{|c|}{$\log \frac{\text { client hours }}{\text { hours worked }}$} & \multicolumn{3}{|c|}{ log average $\mathrm{P}$} \\
\hline & $(1)$ & $(2)$ & $(3)$ & $(4)$ & $(5)$ & $(6)$ & $(7)$ & $(8)$ & $(9)$ \\
\hline \multicolumn{10}{|l|}{ A. Appearance } \\
\hline Beauty & $\frac{.2}{(.04)^{* * *}}$ & $\begin{array}{c}.19 \\
(.04)^{* * *}\end{array}$ & $\begin{array}{l}.12 \\
(.05)^{* *}\end{array}$ & $\frac{.14}{(.05)^{* * *}}$ & $\begin{array}{l}.12 \\
(.06)^{* *}\end{array}$ & $\begin{array}{l}.007 \\
(.07)\end{array}$ & $\begin{array}{c}.04 \\
(.02)^{* *}\end{array}$ & $\begin{array}{c}.05 \\
(.02)^{* * *}\end{array}$ & $\begin{array}{c}.05 \\
(.02)^{* *}\end{array}$ \\
\hline$C_{1}$ & $\mathrm{Y}$ & $\mathrm{Y}$ & $\mathrm{Y}$ & $\mathrm{Y}$ & $\mathrm{Y}$ & $\mathrm{Y}$ & $\mathrm{Y}$ & $\mathrm{Y}$ & $\mathrm{Y}$ \\
\hline$C_{2}$ & $\mathrm{~N}$ & Y & $\mathrm{Y}$ & $\mathrm{N}$ & Y & Y & $\mathrm{N}$ & $\mathrm{Y}$ & $\mathrm{Y}$ \\
\hline$C_{3}$ & $\mathrm{~N}$ & $\mathrm{~N}$ & $\mathrm{Y}$ & $\mathrm{N}$ & $\mathrm{N}$ & Y & $\mathrm{N}$ & $\mathrm{N}$ & $\mathrm{Y}$ \\
\hline F statistic & 10.4 & 9.36 & 9.11 & 4.19 & 3.91 & 3.95 & 8.78 & 8.29 & 7.86 \\
\hline$\overline{R^{2}}$ & .24 & .23 & .24 & .12 & .12 & .13 & .22 & .23 & .23 \\
\hline Observations & 1180 & 1178 & 1178 & 1091 & 1090 & 1090 & 1089 & 1089 & 1089 \\
\hline \multicolumn{10}{|c|}{ B. Collapsed appearance category } \\
\hline Above average beauty & $\frac{.2}{(.06)^{* * *}}$ & $\begin{array}{c}.21 \\
(.06)^{* * *}\end{array}$ & $\begin{array}{c}.17 \\
(.07)^{* *}\end{array}$ & $\begin{array}{c}.21 \\
(.08)^{* *}\end{array}$ & $\begin{array}{c}.19 \\
(.09)^{* *}\end{array}$ & $\begin{array}{l}.14 \\
(.11)\end{array}$ & $\begin{array}{c}.03 \\
(.03)\end{array}$ & $\begin{array}{c}.05 \\
(.03)^{*}\end{array}$ & $\begin{array}{l}.05 \\
(.04)\end{array}$ \\
\hline Below average beauty & $\begin{array}{c}-.22 \\
(.07)^{* * *}\end{array}$ & $\begin{array}{c}-.21 \\
(.07)^{* * *}\end{array}$ & $\begin{array}{l}-.11 \\
(.08)\end{array}$ & $\begin{array}{l}-.05 \\
(.11)\end{array}$ & $\begin{array}{l}-.04 \\
(.11)\end{array}$ & $\begin{array}{l}.17 \\
(.13)\end{array}$ & $\begin{array}{l}-.07 \\
(.03)^{*}\end{array}$ & $\begin{array}{l}-.07 \\
(.03)^{* *}\end{array}$ & $\begin{array}{l}-.06 \\
(.04)\end{array}$ \\
\hline$C_{1}$ & $\mathrm{Y}$ & $\mathrm{Y}$ & $\mathrm{Y}$ & $\mathrm{Y}$ & $\mathrm{Y}$ & Y & $\mathrm{Y}$ & $\mathrm{Y}$ & $\mathrm{Y}$ \\
\hline$C_{2}$ & $\mathrm{~N}$ & $\mathrm{Y}$ & $\mathrm{Y}$ & $\mathrm{N}$ & $\mathrm{Y}$ & Y & $\mathrm{N}$ & $\mathrm{Y}$ & Y \\
\hline$C_{3}$ & $\mathrm{~N}$ & $\mathrm{~N}$ & $\mathrm{Y}$ & $\mathrm{N}$ & $\mathrm{N}$ & $\mathrm{Y}$ & $\mathrm{N}$ & $\mathrm{N}$ & $\mathrm{Y}$ \\
\hline F statistic & 14.89 & 13.44 & 4.22 & 3.82 & 2.75 & 1.5 & 3.01 & 5.02 & 2.38 \\
\hline$\overline{R^{2}}$ & .24 & .23 & .24 & .12 & .12 & .13 & .22 & .23 & .23 \\
\hline Observations & 1180 & 1178 & 1178 & 1091 & 1090 & 1090 & 1089 & 1089 & 1089 \\
\hline
\end{tabular}

Notes: OLS regressions at the sex worker level; dependent variable is log weekly earnings (US\$) in columns 1-3 (mean 4.74 log US\$) and $\log$ productive hours/total hours worked in columns 4-6 (mean -2.0). $C_{1}$ includes controls for linear and quadratic terms in age, schooling, as well as dummies for marital status, children, city, and interviewer fixed effects. $C_{2}$ includes health status, weight, and years of experience as a sex worker. $C_{3}$ is the communication skills score and the desirability of personality score. The $F$ statistic tests that the beauty coefficients are jointly zero. ${ }^{* * *}$ indicates significance at $1 \%$ level, $* *$ at $5 \%$ level, $*$ at $10 \%$ level. 


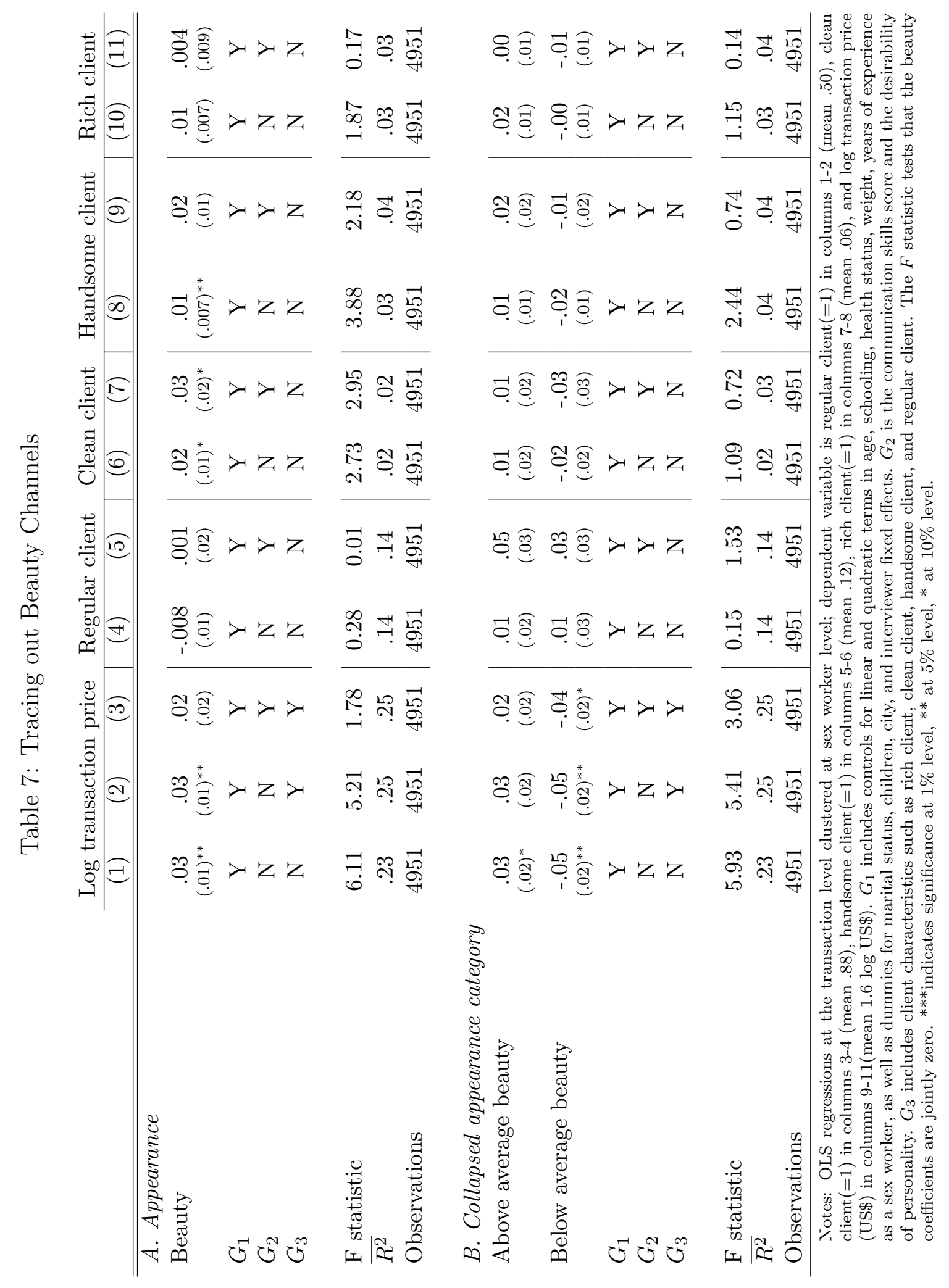




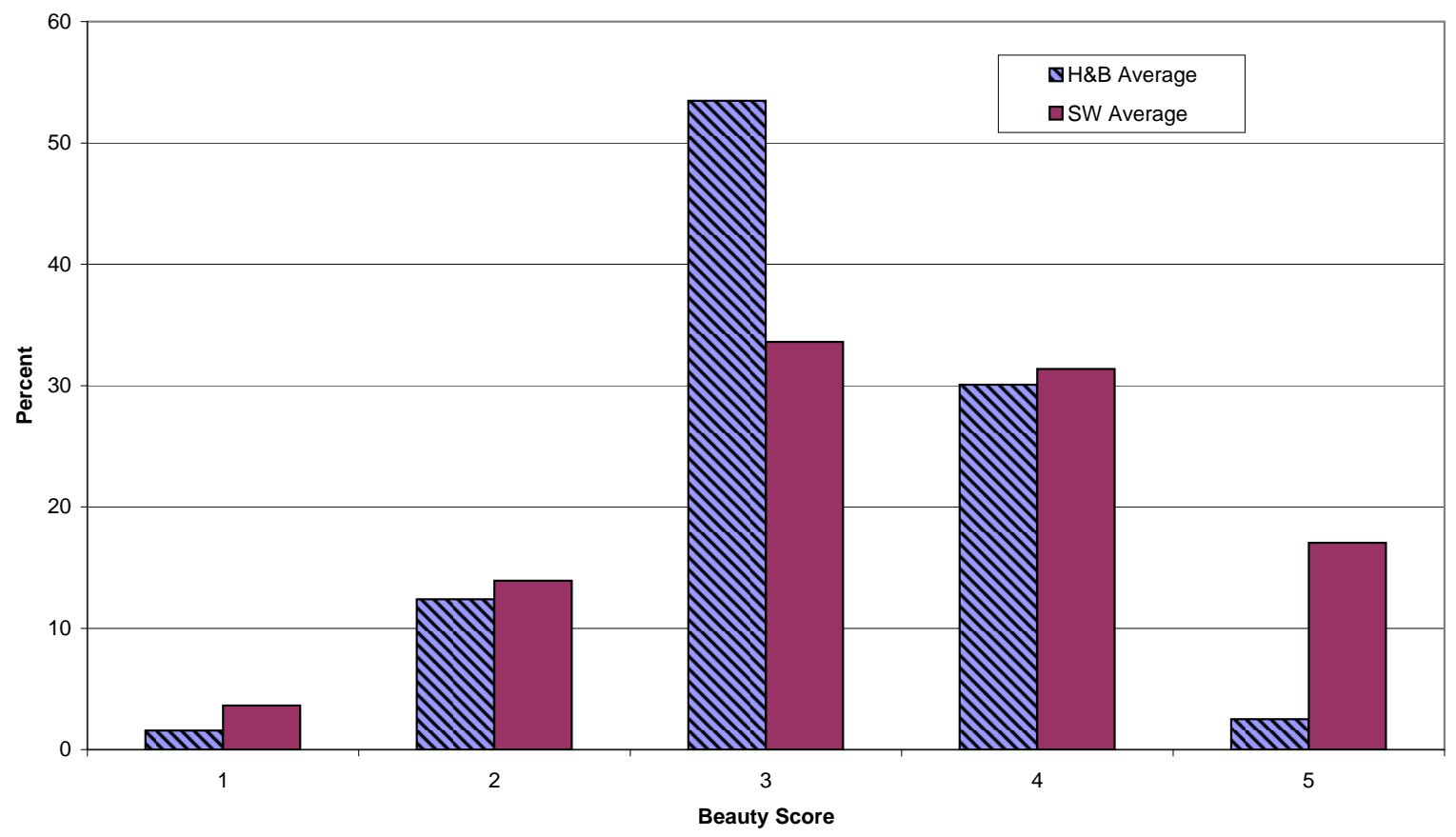

Figure 1: Comparing Beauty Distributions: Sex Worker \& Hamermesh and Biddle (1994) Beauty Data 